\title{
Horseback fighting in Pietro del Monte's Collectanea (1509): from training to the reality of pitched battle
}

\author{
Pierre-Henry Bas, \\ University of Paris 3 Sorbonne Nouvelle, \\ REGHT, \\ bas.pierrehenry@orange.fr
}

\begin{abstract}
The Italian Pietro del Monte left us a wonderful work on the martial arts of the late XVth century. Writing on weapons, gear, and fighting techniques, he gives special attention to horses and horseback fighting. In this succinct article, the goal is to present the two different types of cavalry that are covered directly or indirectly by Monte and to show his wide experience in the field, which led him to suggest some pragmatic techniques and not just write a book showing a wide range of technical and tactical possibilities.
\end{abstract}

\section{Keywords - Horseback fighting, Pietro del Monte, pitched battle}

Pietro del Monte is certainly one of the most famous Italian condottieres of the Renaissance, notably through two of his books, the De dignoscendis hominibus (on the appraisal of men) published in $1492^{1}$ and principally the Exercitiorum atque artis militaris collectanea in 1509, published after his death ${ }^{2}$. In this last work, that we may translate as a " collection of exercises and about military art ", the horse and its use is of paramount importance. Indeed, despite the revolution in infantry warfare during the XVth century, ${ }^{3}$ principally due to the use of pikes ${ }^{4}$ and the increasing role of gunpowder, the cavalry is still a necessity on the field. Horseback fighting is used in several contexts, two of which are particularly detailed by Pietro del Monte. The first is that of the duel, one versus one. The second, which is the pitched battle, is a little more succinct. For Monte, handling weapons in various duel scenarios seems to be a pertinent exercise and good preparation for the more specific framework of the pitched battle. Technically, what distinguishes these two contexts is the availability of space and the freedom of movement of the fighters. For example, in a duel, Monte explains that the fighter focuses on a single opponent, observing his weaknesses and the gaps in his protections in order to strike

\footnotetext{
1* Special thanks to Sebastien Causse for the proofreading

2 Pietro del Monte, Pietro Monti, Petrus Montius (1457-1509). Monte, Exercitiorum Atque Artis Militaris Collectanea. Edited by Forgeng, Pietro Monte's Collectanea. On Monte's writings, see Fontaine, Le condottiere Pietro del Monte, philosophe et écrivain de la Renaissance.

3 Contamine, Philippe, La guerre au Moyen Agge (Paris: Puf, 1980), p. 250.

${ }^{4}$ Gaïer, Claude, «L'influence des Suisses sur la tactique des armées liégeoises », in Armes et combats dans l'univers médiéval, (Bruxelles: De Boeck -Wesmael, 1995), t.1, p. 100.
} 
them. In contrast, in a pitched battle and mass warfare, the enemies defend themselves mutually, and bodies jostle each other. It is a real melee and therefore, it is impossible to focus on only one opponent, and thereby risk getting hit and wounded by another ${ }^{5}$.

Proper preparation is obviously necessary in order to be ready for these different types of confrontations. This includes using an adequate outfit in the form of arms and armor, a point very dear to Pietro del Monte, who gives us a lot of details on their different forms and materials ${ }^{6}$. Concerning cavalry, we may differentiate, through his work, two types of riders. The first are outfitted with light armor and protection, perhaps in a Hispanic or Oriental fashion. The second wears the white harness, the full plate armor, and embodies the traditional heavy cavalry. The equipment can be further modified depending on the expected tactical situation of the fighter, such as a frontal engagement or a surprise attack. Different tactical configurations may occur in a war, whether in a pitched battle or during skirmishes (called scaramuciare ${ }^{7}$ ). This is also true in regulated duels, whether deadly or not, for which there are many different conventions. These conventions and regulations are very important, as they define what is allowed or forbidden, and therefore which techniques and tactics are available to the fighter. For example, in a duel at the barrier or in a closed field, Monte mentions that it is essential to know if it is allowed to strike and kill the opponent's horse ${ }^{8}$. This tactic is not usually allowed in dueling conventions, as Monte specifies, but remains one of the most effective actions to defeat an enemy, and as such, it is important to know if this is an option. In contrast to the regulated duel, war includes less honorable fighting tactics of two sorts: one is harassment and evasion, including tactical retreats and feigned flights, at which light cavalry excels. The second is the confrontation of a rider against a footman, regarded as not honorable unless the footman is a rider that had been previously dismounted during the fight.

Dueling in harness generally applies to different contexts: pitched battle, skirmish, and standardized duel. In all of these contexts, specific training is required, which also depends on the equipment used. For example, allowing harassment tactics can lead to choosing to practice handling the light leather shield of Moorish fashion, the adarga, and the light spear, the jineta. The latter can be thrown, which led Monte to give us some valuable advice on how to throw the spear or the javelin, which can be done on foot and horseback. In that last case, the rider stands on the two stirrups adjusted to the same length. The feet are set firmly in the stirrups, the arm is stretched and the body turns during the throw. This method should prevent the rider from tipping forwards or backwards 9 . At the opposite end of the spectrum, choosing frontal combat in heavy harness usually means using the heavy lance, and training in the art of jousting. This subject is quite well developed in Montes' work, even if it seems to be limited to traditional

\footnotetext{
${ }^{5}$ Monte, Exercitiorum Atque Artis Militaris Collectanea, op.cit., book 2, ch.LXXIX.

${ }^{6}$ Ibid., book 2, ch.CIV to ch. CXXVIII.

${ }^{7}$ Ibid., book 2, ch.LXXXV.

8 Ibid., book 2, ch.LXXIII, ch.LXXIV, ch.LXXIX.

${ }^{9}$ Ibid., book 1, ch.XXIII.
} 
jousting, with the lance crossed over to the left, both fighters riding past each other on the left, and using specific equipment ${ }^{10}$. This is somewhat different from dueling with the lance, where the riders may, for example, pass each other on the right; a situation that we find notably in the German fightbooks of the same period and the writings on horseback fighting attributed to the master-at-arms Johannes Liechtenauer ${ }^{11}$.

Montes' writings, however, seem to be closer to the reality of the field and of war than the usual German technical literature. The condottiere is one of the very few authors to explain the use of typical heavy cavalry weapons, such as warhammers, namely bec de corbin or bec de faucon (raven's or falcon's beak) in French sources ${ }^{12}$. This type of weapon is sometimes substituted with a short axe $(a z a)$ or a mace $(m a z z a)^{13}$. The other hand to hand weapon is the sword. This weapon follows the same principles as other arms, be it on foot or horseback. Monte advises some feints based on the observation that no guard or defensive position is absolutely safe. Thus he advises constant and quick movement in order to create a window of opportunity to strike the opponent in an uncovered target after a feigned threat ${ }^{14}$. The sword can be replaced by the tuck (mucro), a weapon typical of this period ${ }^{15}$. The shape of this weapon is similar to that of a sword, with a thin blade of square or triangular cross section. The sides are sometimes concave, and the guard is usually straight. It is used primarily for thrusting, whereas the sword is used for both cutting and thrusting. The protection offered by the harness, especially for the face and the left arm, increases the opportunities for wrestling or disarming the opponent. We will see later on that the protected arm can be used to parry or deflect blows as a shield, and the lighter blows may be ignored ${ }^{16}$. That is why Monte instructs that in an armored fight, blows must be dealt with great force.

Regarding the fight between a footman and a rider, which can recall the later works of Paul-Hector Mair of the $1550 \mathrm{~s}^{17}$, the suggested tactics seem to be very logical and depends on the weapons and equipment used by the rider and the footman. All these practices are well described in the work of Monte, and a reader accustomed to the literature of German fight books will find it easy to understand. What is more interesting are his reasons on why one should train in these exercises. Sometimes his justifications are hygienist, but more often they are martial. Training a man of war requires developing endurance and

10 Ibid., book 2, ch.LXXXXIV to ch.CIII.

${ }^{11} \mathrm{~B}$ as, «Les plus périlleuses armes du monde sont à cheval ».

12 Like axes, some models are shorter to be use with only one hand and other are longer to be use as a poleaxe with two hands in the context of the fight on foot. Cf. for ex. Clephan, The Medieval tournament, p. 54.

13 The maza can sometimes corresponds to a warhammer. Fontaine, «Dénomination de quelques armes d'hast », p.53-104.

${ }_{14}$ Monte, Exercitiorum, book 2, ch.XLV.

15 Ibid., book 2, ch.LXVI, ch.LXXIVand LXXV.

16 Ibid., book 2, ch.LXXIX.

${ }^{17}$ For example: Paul-Hector Mair, fol. 269r, pl.1, to fol. 275v, pl.14. 
strength. For this purpose, wrestling is regarded as fundamental ${ }^{18}$. This opinion is shared with another great figure of the XVth century: king Dom Duarte of Portugal (1391-1438), who wrote the Livro da ensinanca de bem cavalgar toda sela (the Book of the art of riding with any type of saddle $)^{19}$ around 1434, a book about horse riding, in which he argues in favor of the practice of wrestling.

One must add the handling of different weapons on foot, and other practices which require a horse, to this basic training. This is primarily horseback riding, even if Monte is laconic on riding itself and prefers to write on equestrian vaulting ${ }^{20}$. This practice consists essentially of acrobatic moves performed on a harnessed horse. The high pommels of the medieval saddle are grasped with one or two hands, and the rider jumps on and around the horse ${ }^{21}$.

Finally, choosing a horse is just as important as choosing one's equipment ${ }^{22}$. Monte is one of the rare authors to state the importance of the physiognomy, personality, idiosyncrasy, and behavior of the fighter. Naturally, he does the same for the horse, even if his comments are brief. The horse with a good spirit, brave, trained, and especially stronger, more powerful and taller than that of the opponent offers a significant advantage in a fight ${ }^{23}$. This important advantage is the reason why neutralizing it with a disabling or killing blow is a priority, hence the importance of knowing if hitting the horse is allowed in a duel, as Monte stated. This is especially true if the rider is armored and therefore harder to harm. Thus the chapters dealing with horses in Monte's works oscillate between purely artificial physical disciplines, like vaulting on a horse, and very pragmatic techniques, that take into consideration all possible options in order to quickly knock off the opposing rider.

All in all, in order to do well in duels or war, the athletic exercises of wrestling and vaulting, and the handling of weapons in duels, and jousting are all necessary practices. Indeed, Monte places a lot of importance on versatility. The key is to know how to transfer a skill from one art to another. Those who practice an art only in a single manner will remain eternal beginners ${ }^{24}$.

By understanding how Monte looks at horseback fighting, we can conduct a step by step study of the various techniques he exposed. We will take three examples:

- First, the various steps of typical chivalric fighting, including the use of the spear and other shorter weapons.

${ }^{18}$ Monte, Exercitiorum, book 2, ch.II.

${ }^{19}$ Dom Duarte, Livro da Ensinança de Bem Cavalgar.

${ }^{20}$ Fontaine, «La voltige à cheval chez Pietro del Monte », p.197-252.

${ }^{21}$ Monte, Exercitiorum, book 1, ch.XIX.

22 Ibid., book 2, ch.LXXVII and ch.LXXXII.

${ }^{23}$ Ibid., book 2, ch.LXXIV and ch.LXXXXII.

${ }^{24}$ Ibid., book 1, ch.XLIX. 
- Second, the equipment and some tactical and technical choices for light cavalry.

- Finally, the technical and tactical choice of a footman against a rider.

Horseback fighting goes through three stages directly related to the combat distances or measures involved. We can also find these in German fight books through the use of the lance, the longsword, and wrestling. The first is used as the two knights meet, as in jousting. In the second step, each fighter tries to dominate their adversary and hit him with a sword or a mace. Finally, at the shortest distance, wrestling is used to either disarm, lock the opponents' arms, or throw him off his horse. The different tactics are very well described $^{25}$. Some are quite similar to those that can be found in the German fight books, specifically for arm wrestling, where the opponents try to twist each other's arms into different locking positions with both horses facing the same direction, as in a pursuit, or in opposite directions, when coming face to face.

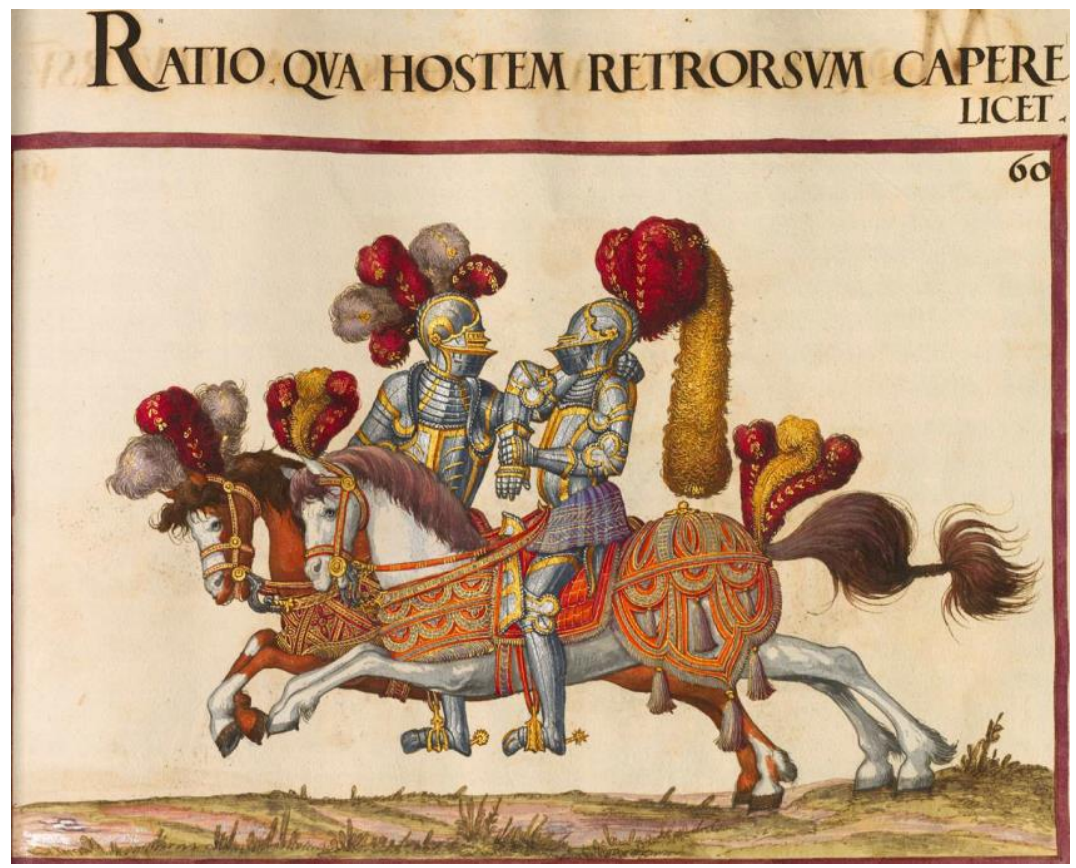

Figure 1: Ratio, qua hostem retrorsum capere licet. "A way, which allows to grab the enemy from bebind". Mair, Paul-Hector, De Arte Athletica (München: Bayerische

Staatsbibliothek, Cod.icon.393, middle of the 16th century, t..II, pl.60, f $\mathrm{f}^{\circ} 198 \mathrm{r}^{\circ}$ )

Reproduced with permission of the institution.

However, the most remarkable element is the description of the Turkish cut, or Turckishbaw in German sources, a blow with the sword which Monte also attributes to the Turks and the Moors. This cut consists of hitting the opponent a second time in the back, in the event that he has parried the first frontal strike, and is done as the two riders pass each

${ }^{25}$ Ibid., book.2, ch.LXXIX. 
other. Monte also offers a key to reading horseback fighting, which is only hypothetical and implied in the German fight books. A fight between two knights, each equipped with lance and sword, may be divided in three phases. Each phase is characterized by the use of one type of weapon. In the first phase, the goal of a horse rider is to thrust at the opponent with the lance. To do this, he should always point his tip against him, and thrust him at the face or chest. This type of combat must be linear, even if in reality the horse is at a slight angle, as for jousting, in order to receive full frontal impact. The second phase of fighting is done with the mace or the warhammer, which is sometimes held in both hands. Once again, Monte is very clear: in a white harness it is necessary to hit with as much force as possible to wound the opponent. This is not the case with lighter equipment where all strikes are potentially harmful. Moreover, wearing a harness not only allows the fighter to ignore light blows to the skull, but also to parry blows with the left arm, so as to attack simultaneously with the weapon in the right hand. When fighting with shorter weapons, the goal is to keep one's' horse's head facing the opponent, even if there are occasional frontal passes where riders cross each other on the right. Ideally, one should try to get to an advantageous position, facing the croup of the opposing animal, and then hit the enemy in the back. The fight is therefore essentially circular, like in a dogfight. Alongside these bludgeoning weapons that can also be used to parry or hook the opponent, swords and tucks are used against the gaps of the cuirass, which are the same as those when fighting in armor on foot: the sights on some types of helmets, the visor, the throat or the armpits. But to strike correctly on horseback with a cut or thrust, it is necessary to maintain a certain range: the measure. Monte reminds us that on horseback, it is impossible to go back: one can either stay on the spot or advance to bypass the opponent. This is why in some cases the opponent is too close for weapons and it is necessary to use ones' arm to grab the opposing arm, to disarm him or grab his neck and wrestle. All the while keeping control of the reins, which is why the bridle can be attached to the mane by a string or be long enough to pass behind the left arm without pulling on the horses' mouth. It would be indeed catastrophic to lose control of one's mount, which should normally be pushing against the opposing horse. Hence the importance of the proper use of legs and spurs, and more generally, the art of horseback riding.

The riding style of the late fifteenth century is still the "brida", as explained by king Dom Duarte, on the so-called "brabante" war saddle, with a high pommel at the front and a strong cantle at the back. This helps hold the rider tightly and enables him to lean slightly forward, legs outstretched, standing firmly on the stirrups with buttocks pressed against the cantle during the charge. This manner of riding a horse is very different from another way also described in Duarte's book, the so-called "gineta" style, characterized by the use of shorter stirrups and riding with bent legs. This riding style is native of the Maghreb, which then transited through the Hispanic Peninsula and Lusitania. Riding in the jineta style is done using very different saddles, with the rider seated on the middle section of his horse. This style, described for the first time in the work of Dom Duarte, is usually used by the lighter cavalry. Monte advises using it mostly for racing and for throwing projectiles. However, this riding style can also be used for fighting or hunting. Some riders use a light spear also called the jineta (lancea), which they hold in the middle with the right 
hand. It is possible to do some feints with it, such as pretending to throw the spear, and switching to a thrust as the opponent tries to avoid the throw. This type of weapon can also be held in the left and right hands at the same time to thrust with force. The left hand also holds the leather shield or adarga which should always serve as a screen against the opponent, but without ever obscuring one's own view. This gear can be used both for harassing and fleeing before force. Against a stronger and better armed cavalry, Monte explains how to pretend to accept a charge from an enemy lancer by coming to meet him and then dodging him at the last moment. For Monte, skirmishing or light combat on horseback can be very similar to fighting on foot:

Anyone who knows how to move and protect himself well on foot, if he is judicious and sagacious, can do similarly on horseback, as long as he knows something about horsemanship, in which case he can easily do on horseback whatever he does on foot.

This choice to let the opposing knight come close is an option for the light rider, but a footman does not have any other choice. Monte, who often combines psychology with combat tactics, states that this configuration is very stressful for a man on foot. Nevertheless, Monte adds that it remains difficult for a knight to hit an armed footman protected by armor, and that there is a good chance of only knocking him to the ground. The footman may throw a light spear or a stone when the horseman is forty or fifty footsteps away. He can also dodge the charge by jumping off to the side and striking at the horse or its rider. In any case, the key is to reduce the impact of the charge. In addition, if the footman falls to the ground and is protected by armor, and the opposing rider is not armed with a long lance but a shorter weapon with limited range, the footman should remain on the ground. He can then use his weapon to strike at the belly of the horse several times, "like a wolf". This is effective, as even when caparisoned, the horses' belly is always unarmored. This technique is, according to Monte, more mentally and physically hard than technically difficult, despite the danger of being trampled by the horse's feet.

Thus, through these few equestrian examples, we see how Monte, in his own way, fills the gap that seems to sometimes exist between very theoretical German fightbooks and the reality in the field. In fact, in German fightbooks like Paul-Hector Mair's works, German authors and masters-at-arms often make the choice of multiplying techniques, theoretically covering every situation and context without going into details. Those can be a duel, a playful competition, or an aggressive encounter in the street. In contrast, Monte is really a man of war. Although he gives less technical solutions to win against an opponent in a serious context, in a more pragmatic way Monte reminds us of the importance of the mind, of working out, and of proficiency with weapons. In addition to fencing, he explains that the exercise of wrestling, vaulting, and running with or without the help of a horse, aim to strengthen the body and the desire to dominate in combat. Another truth missing from other fightbooks is that exercise of horse riding is essential for fighting on horseback.

Therefore, the techniques that are used depend both on the material context, and the type of weapon or armor that allows the technique. Monte is one of the rare authors to show 
that practicing with weapons helps to prepare for dueling situations where there are limits in the freedom of the exchange through some convention or regulation. However, for Monte, military combat and pitched battles are never very far from a normalized duel. The difference is essentially in the choice of the techniques used to complete the objective. A technical choice that is only possible if one has the strength, endurance, mastery, skill, and mental fortitude necessary for its application. That is why training is necessary.

To conclude, the following illustration shows the relations between the techniques and tactics used in fighting: the fighter's skill level determines which techniques are achievable. These parameters are in direct relation with the materials and the weapons used, as well as the physical and mental conditions of the fighter. The techniques allowed in the fight are defined by the rules and conventions, but at the same time, their usefulness depends on the context, which range from the "anything goes" situation of pitched battle to the more regulated encounters like duels. Indeed, these contexts determine the rules and the conventions, such as the right to kill the opponent's horse mentioned earlier. This rationale is clearly visible when it comes to horseback fighting as described by Pietro del Monte, where there are great differences between light and heavy cavalry, and pedestrian versus horseman. This relation between skills, weapons, techniques, and rules is also true for other martial arts from the Renaissance, where we can connect theories and practices, sword games, duels and the reality of war.

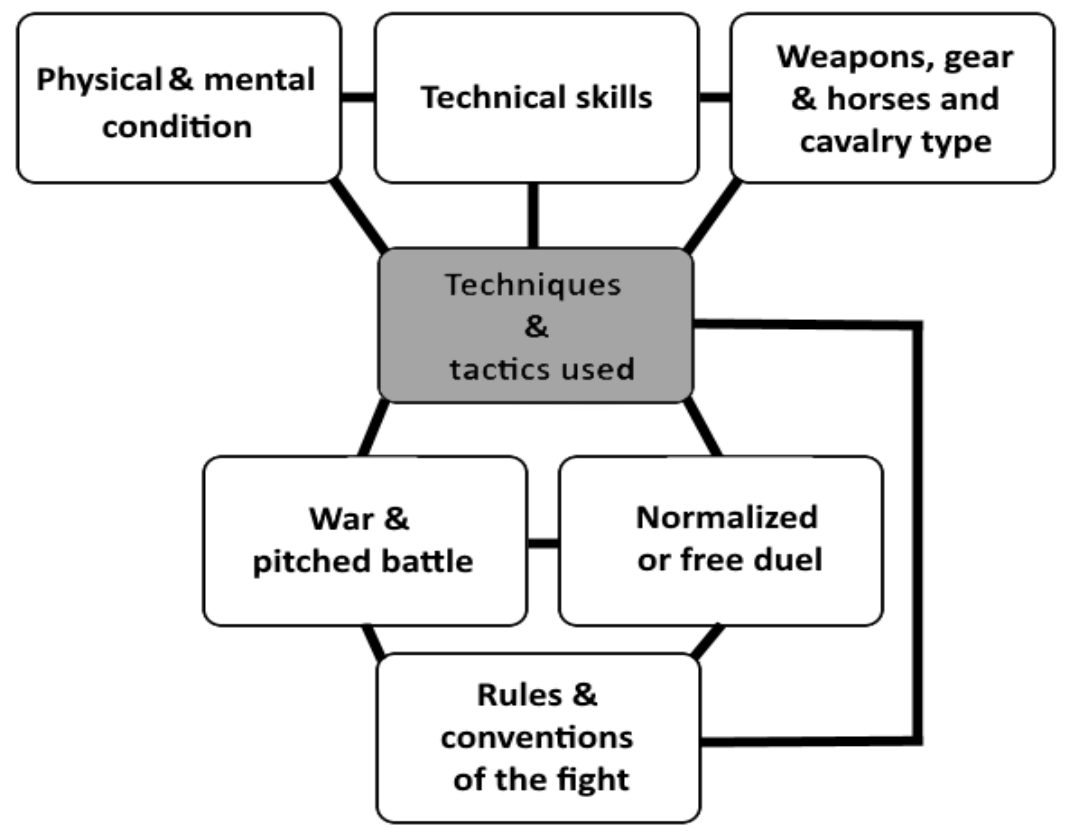

\section{Relations between the techniques and the tactics used in fighting, according to different parameters in Pietro del Monte work's.}

Figure 2: Relations between the techniques and the tactics used in fighting by the horseman in function of the contexts, rules and conventions and other parameters. By the author. 


\section{BIBLIOGRAPHY}

\section{Primary sources}

Dom Duarte, Livro da Ensinança de Bem Cavalgar Toda Sela, ca. 1434 (Paris, Bibliothèque nationale de France, Portugais 5).

Paul-Hector Mair, mid $16^{\text {th }}$ c. (Dresden,Sächsische Landesbibliothek, ms Dresd C.93 and ms C.94).

Paul-Hector Mair, De Arte Atbletica, mid 16th c. (München, Bayerische Staatsbibliothek, Cod.icon.393, t. I et II).

Pietro del Monte, Exercitiorum Atque Artis Militaris Collectanea, Milan, Giovani Angelo Scinzenzler, 1509.

\section{Secondary literature}

Bas, Pierre-Henry, «Les plus périlleuses armes du monde sont à cheval et de la lance car il n'y a point de holla » : introduction au combat équestre d'après les sources germaniques, XVe-XVIe siècle », in L'art chevaleresque du combat, le maniement des armes à travers les livres de combat (XIVe-XV le siècle) (Neuchâtel: Alphil, 2013), p.187-203.

Clephan, R. Cotlman, The Medieval tournament (London: Methuen \& Co. repr. 1995).

Contamine, Philippe, La guerre au Moyen Agge (Paris: Puf,1980).

Fontaine, Marie-Madelaine, Le condottiere Pietro del Monte, philosophe et écrivain de la Renaissance, 1457-1509 (Geneva and Paris: Slatkine, 1991).

Fontaine Marie-Madelaine, «Dénomination de quelques armes d'hast dans les exercitiorum collectanea du condottiere Pietro Del Monte (1509)", in Les mots de la guerre dans l'Europe de la Renaissance (Genève : Droz, 2015), p.53-104.

Forgeng, Jeffrey L., Pietro Monte's Collectanea. The Arms, Armour and Fighting Techniques of a Fifteenth-Century Soldier (Woodbridge: Boydell Press, 2018).

Gaïer, Claude, «L'influence des Suisses sur la tactique des armées liégeoises », in Armes et combats dans l'univers médiéval (Bruxelles: De Boeck -Wesmael, 1995).

Pereira, Carlos, Naissance et renaissance de l'équitation portugaise. Du XVe au XVIIIe siècle d'après l'étude des textes fondateurs (Paris: l'Harmattant, 2010), p.75-81.

Preto, Antonio Franco, The royal book of horsemanship, jousting and knightly combat. Dom Duart's 15th century Bem Cavalgar Toda Sela (Highland Village: Chivalry Bookshelf, 2005).

Quint, Anne-Marie, Pereira, Carlos, Le traité des équitations. Livre qui enseigne à bien pratiquer toute équitation (Arles: Actes Sud, 2016). 